\title{
Where was Joseph Babinski born?
}

\author{
Hélio A.G. Teive'1, Renato P. Munhoz², Leonardo Cruz de Souza ${ }^{3}$
}

\section{ABSTRACT}

There is controversy in the neurological literature about where Joseph Babinski was born, including a myth propounded by various important authors that he was born in Lima, Peru. However, according to the most consistent biographical data, he was in fact born in Paris, France, and became a medical celebrity there and in Poland as well as around the world. Key words: Joseph Babinski, Babinski, Lima, Peru, Paris, France.

\section{Onde Joseph Babinski nasceu?}

\section{RESUMO}

Existe uma controvérsia na literatura neurológica acerca do local de nascimento de Joseph Babinski, incluindo a lenda nutrida por vários autores de importância, de que ele teria nascido em Lima no Peru. Contudo, os dados biográficos mais consistentes definem que ele nasceu de fato, na cidade de Paris, França, tornando-se uma celebridade da medicina francesa, polonesa e mundial.

Palavras-chave: Joseph Babinski, Babinski, Lima, Peru, Paris, França.

Józef Julian Franciszek Feliks Babinski, whose Gallicized name was Joseph François Felix Babinski, but was best known simply as Joseph Babinski (Fig 1), was one of the most famous disciples of professor Jean-Martin Charcot, head of the neurology service at the Salpêtrière hospital in Paris, France, and considered the father of modern neurology $y^{1,2}$. Joseph Babinski was head of the neurology service at the La Pitié hospital in Paris and became world famous because of his scientific production, which included studies in neurological symptomatology, a description of various signs of cerebellar syndrome and descriptions of diseases such as Babinski-Fröhlich syndrome, BabinskiNageotte syndrome and Anton-Babinski syndrome $e^{2-5}$. Various neurological signs were also described by Babinski, most notably the reflex that made him world famous, the Babinski sign, or "toe phenomenon", which he described in $1896^{2,6-11}$.

According to his official biography, Joseph Babinski was born on November 17, 1857, in Paris to parents of Polish origin.

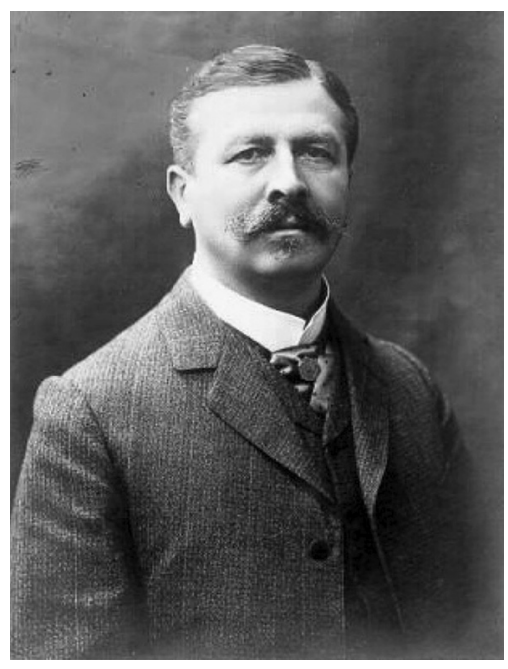

Fig 1. Joseph Babinski (1857-1932). Extracted from http://commons.wikipedia.org/wiki/ Image:Joseph_Babinski.jpg.

However, this has been the subject of debate in the literature, and it has been suggested that he was born in Lima, Peru, or even in Warsaw, Poland ${ }^{2,12,13}$. The aim of this study is to review the main biographical literature about Joseph Babinski, focusing primarily on his place of birth.
Hélio A.G. Teive

Rua General Carneiro 1103/102 80060-150 Curitiba PR - Brasil E-mail: hagteive@mps.com.br

Received 14 December 2010 Received in final form 20 December 2010 Accepted 27 December 2010
'Head of the Neurology Service, Hospital de Clínicas, Federal University of Paraná, Curitiba PR, Brazil; ${ }^{2}$ Neurologist, Movement Disorders Unit, Neurology Service, Internal Medicine Department, Hospital de Clínicas, Federal University of Paraná, Curitiba PR, Brazil; ${ }^{3}$ Neurologist, Université Pierre et Marie Curie- Paris 6, Centre de Recherche de l'Institut du Cerveau et de la Moelle Epiniére, UMR-S975, Paris, France. 


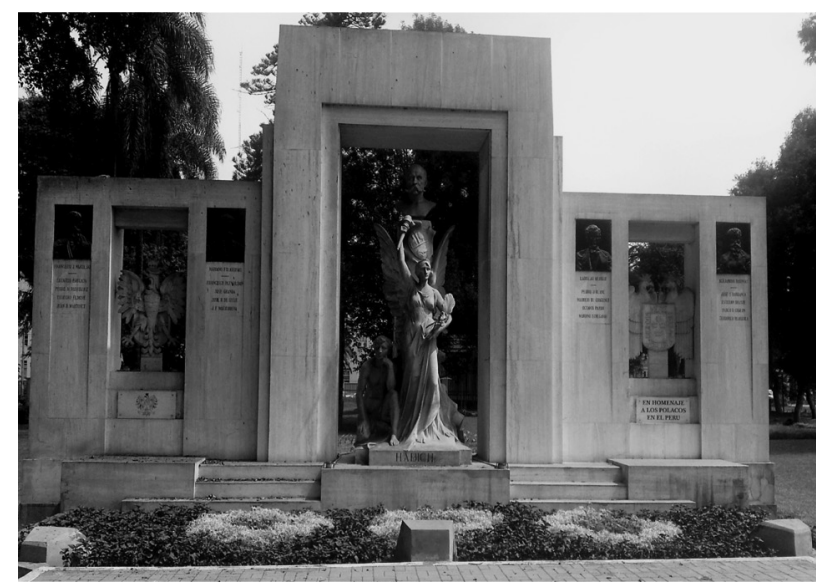

Fig 2. Monument in tribute to the Polish in Peru at the Poland Park, Lima, Peru. The black rectangle on the right is highlighted in Fig 3. Photograph by Renato Puppi Munhoz (personal archive).

\section{The Babinski family}

Joseph Babinski's parents, Aleksander Babinski (18231899) and Henryeta Weren-Babinska (1819-1897), were born and married in Poland and emigrated to France immediately after the Polish Revolution in $1848^{1,12}$. They had two sons, Henry, who was born in 1855, and Joseph, who was born in 1857. Joseph Babinski's father, Aleksander Babinski, was a civil engineer and worked as a surveyor in the Quarry Inspection Department ("Inspection des Carrières") in Paris ${ }^{2,12}$. There are reports that Aleksander Babinski took part in the Polish rebellion of 1848 and that later, when living in Paris, he also took part in the 1863 rising in Warsaw, Poland. There is also evidence to suggest that Aleksander took part in the Paris Commune in $1871^{2,12}$.

After a period in Paris, Aleksander Babinski received an offer from Pedro Galvez, the Peruvian envoy in Paris, of an important position in Lima that would allow him to support his family and pay for his children's education. The records show that Aleksander Babinski worked in Lima for a long time and was even involved in defending Peru in the war against Chile in 1879 . He returned to Paris in $1887^{2,12,13}$.

In recognition of his work, dedication and honesty, the Peruvian government had a monument with his bust erected in the Jesús María district, one of the most centrally located districts of Lima (Fig 2). The monument is located in a square divided into two parks, the Habich and Poland Parks. Aleksander Babinski's bust is part of the monument "In Tribute to The Polish in Peru" (en homenaje a los polacos en el Peru) built in 1911 in bronze and marble by the French sculptor Carlos Libero Valente Perrón in memory of Polish immigrants (Fig 3). The Eastern part of the square, the Habich Park, received its name after Edward John Habich, an engineer

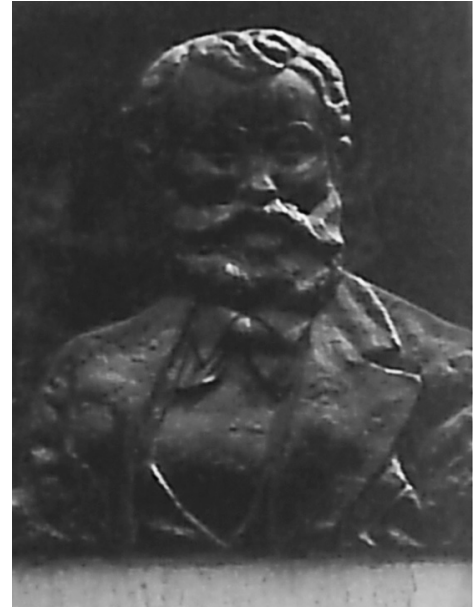

ALEJANDRO BABINSKI
Fig 3. Detail of the bust monument to Alexander Babinski, part of the the Polish in Peru at the Poland Park, Lima, Peru. Photograph by Renato Puppi Munhoz (personal archive). monument in tribute to

and mathematician who was a professor at the University of Warsaw and founded in 1876 the Universidad Nacional de Ingenieria in Lima, the most important engineering school in the country $y^{2,13}$

Despite adapting well to French customs and life in Paris, Henryeta and Aleksander never applied for French citizenship and always maintained close ties with the Polish community in Paris ${ }^{2,12}$.

Joseph Babinski's brother, who was well-built, was called "the big", while Joseph was known as "the blond giant with blue eyes" ${ }^{2}$. Henri qualified at the prestigious "École des Mines de Paris" in 1875 and worked in countless countries, including various Latin America ones, most notably Brazil, in the state of Bahia, where he supervised work in diamond and carbon mines ${ }^{2}$. After his parents' deaths, Henri returned to Paris to live with his brother Joseph and became a gastronomic expert, even publishing a book on the subject in 1907 with the title "Gastronomie pratique, Études Culinaires" (Encyclopedia of Practical Gastronomy) under the pseudonym Ali-Bab. This became very well known and achieved considerable success, becoming a reference for gourmets. It includes references to exotic cuisines, such as "feijoada", the national dish of Brazil" ${ }^{2,14}$. The inseparable Babinski brothers became very well-known in Parisian intellectual circles, and Henri developed an intense admiration for Joseph (who was for him "like a god"). Indeed, while Joseph dedicated himself exclusively to science, Henri dedicated himself completely to his younger brother ${ }^{2}$. Although living in Paris and considering themselves true French citizens, the Babinski brothers always kept close ties with Polish culture and were actively involved in cultural institutions such as the Polish School in the Batignolles district ${ }^{2}$.

Henri Babinski died in 1931, one year before his 
brother, who died in 1932 after developing Parkinson's disease. Both were buried in the Babinski family tomb in the Champeaux cemetery at Montmorency, near Paris ${ }^{2,12}$.

\section{Where was Joseph Babinski born?}

Although the official biography of Babinski states that he was born in Paris in 1857, there is published information suggesting that he may have been born in Lima or even Warsaw ${ }^{2,13,15}$.

A myth propounded by some authors suggests that he was born in South America, in Lima, Peru ${ }^{13,15}$. In the article "Influencia de La Medicina Francesa en La Medicina Peruana", published in 2002, Cuba reports that various Peruvian historians, including Valdizán and Basadre, confirmed with Joseph Babinski himself that he was born in Lima when his family was living there in the $19^{\text {th }}$ century. According Cuba's paper "El historiador peruano Enrique Basadre, habria hablado personalmente con el profesor Babinski, quien le habría confirmado este hecho" ${ }^{13}$. Lhermitte, in his famous article of 1957 based on his lecture at L'Académie Nationale de Medicine, with the title "J. Babinski (1857-1932): Éloge", discussed Babinski's place of birth and considered the possibility of his having been born in Lima quite convincing. "Si la date de naissance du futur neurologiste se situe au 17 novembre 1857, sés biographes fixent le lieu de sa naissance, qui à Paris, qui à Varsovie, qui enfin à Lima"15. This idea, however, was vehemently refuted by other researchers, such as Tournay, who stated in 1958 in a classic article "Babinski dans la vie" corroborated by a variety of biographical data, that Joseph Babinski really was born in Paris ${ }^{2,16}$. According Tournay, this information is supported by civil status document and the testimony of Babinski's friends ${ }^{16}$. In addition, in 1958, in a homage to the memory of Joseph Babinski on the centenary of his birth, Moreau stated that Babinski was born in Paris in 1857 ("Il y a cent ans, Babinski nassait à Paris") 17.

The majority of the biographical evidence thus indicates that Joseph Babinski was in fact born in Paris and that the suggestion that he was born in Lima has no scientific basis, particularly because of his date of birth (1857) and the period when his parents lived there $(1874-1887)^{2,16,17}$.

In spite of the controversy surrounding the true birthplace of Joseph Babinski, including the myth propounded by various important authors, such as professor Lhermitte, that he was born in Lima, the most consistent autobiographical data indicate that he was born in 1857 in Paris, later to become a medical celebrity in France and Poland (because of his family's roots), as well as around the world.

ACKNOWLEDGMENTS - We would like to thank Professor Zbigniew K. Wszolek (Department of Neurology, Mayo Clinic, Jacksonville, FL, USA), for his support.

\section{REFERENCES}

1. Goetz CG, Bonduelle M, Gelfand T. Charcot. Constructing neurology Oxford University Press, New York, USA, 1995.

2. Philippon J, Poirier J. Joseph Babinski. A biography. Oxford University Press, New York, USA, 2009:3-21, 97-131, 151-185, 187-216, 217-248.

3. Massie R. Charcot and Babinski: beyond a simple teacher-student relationship. Can J Neurol Sci 2004;31:422-426.

4. Fine EJ, lonita CC, Lohr L. The history of the development of the cerebellar examination. Semin Neurol 2002;22:375-384.

5. Poirier J. Joseph Babinski: a complex personality. Bull Acad Natl Med 2007; 191:1343-1353.

6. Philippon J. Babinski's legacy. Bull Acad Natl Med 2007;191:1319-1327.

7. Gasecki AP, Kwiencinski H. On the legacy of Joseph Babinski. Eur Neurol 1995;35:127-130.

8. van Gijn J. The Babinski sign: a centenary. Universiteit Utrecht, Utrecht, The Netherlands, 1996:17-84

9. van Gijn J. The Babinski sign: the first hundred years. J Neurol 1996;243: 675-683.

10. Gasecki AP, Hachinski V. On the names of Babinski. Can J Neurol Sci 1996; 23:76-79.

11. Kakitani FT, Collares D, Kurozawa AY, de Lima PMG, Teive HAG. How many Babinski's signs are there? Arq Neuropsiquiatr 2010;68:662-665.

12. Skalski JH, Gladki M, Pyplacz D. The celebrity of Polish and French medicine: Józef Julian Franciszek Feliks Babinski (1857-1932). Pol Arch Med Wewn 2007; 117:327-330

13. Cuba JM. Influencia de la Medicina Francesa en la Medicina Peruana. Rev Peruana Neurol 2002:8:31-40

14. Ali-Bab. Encyclopedia of Practical Gastronomy. McGraw-Hill Book Company, New York, USA, 1974.

15. Lhermitte MJ. J. Babinski (1857-1932). Éloge. Bull Acad Nat Méd 1957;32-33: 727-740.

16. Tournay A. Babinski dans la vie. La Presse Medicale 1958;66:1485-1489.

17. Moreau MR. Hommage à la mémorie de J. Babinski à occasion du $100^{\circ}$ anniversaire de sa naissance. Bull Mém Soc Méd Hôp Paris 1958;74:449-457. 